\title{
Correlation of Menopausal Symptoms and Quality of Life with Physical Performance in Middle-Aged Women
}

\section{Relação entre sintomas climatéricos e qualidade de vida no desempenho físico em mulheres de meia-idade}

\author{
Rívea Trindade da Silva ${ }^{1}$ Saionara Maria Aires da Câmara ${ }^{2}$ Mayle Andrade Moreira ${ }^{1}$ \\ Rafaela Andrade do Nascimento ${ }^{1}$ Mariana Carmem Apolinário Vieira ${ }^{1}$ \\ Maria Socorro Medeiros de Morais ${ }^{3} \quad$ Álvaro Campos Cavalcanti Maciel ${ }^{1}$ \\ ${ }^{1}$ Department of Physiotherapy, Universidade Federal do Rio Grande \\ do Norte, Natal, RN, Brazil \\ 2 Faculty of Health Sciences of Trairi, Universidade Federal do Rio \\ Grande do Norte, Natal, RN, Brazil \\ ${ }^{3}$ Health Sciences Center, Universidade Federal do Rio Grande do \\ Norte, Natal, RN, Brazil \\ Address for correspondence Mayle Andrade Moreira, Master Degree, \\ PhD applicant, Department of Physiotherapy, Universidade Federal do \\ Rio Grande do Norte, Avenida Senador Salgado Filho, S/N Caixa Postal \\ 1524 - Campus Universitário - Lagoa Nova, 59072-970, Natal, RN, \\ Brazil (e-mail: maylinhaandrade@hotmail.com).
}

Rev Bras Ginecol Obstet 2016;38:266-272.

\begin{abstract}
Introduction Some studies have investigated the influence of hormonal deficits and menopausal status in muscle disorders of women. However, it has not been investigated the relationship of both climacteric symptoms and the perception of quality of life with physical performance.

Objective To evaluate the correlation of menopausal symptoms and quality of life with physical performance in middle-aged women.

Methods This cross-sectional study was performed from April to November 2013 in the municipality of Parnamirim, in the Brazilian state, Rio Grande do Norte. The sample was composed of 497 women aged 40-65 years. The Menopause Rating Scale (MRS) and the Utian Quality of Life (UQOL) questionnaire were used to evaluate menopausal symptoms and quality of life respectively. Measures of physical performance included handgrip strength, knee extensor and flexor strengths (using an isometric dynamometer), gait speed, and chair stand test. The correlation between menopausal symptoms and quality of life with physical performance was assessed by Pearson's correlation coefficient with significance set at $p<0.05$ and a confidence interval of $95 \%$.

Results There was a significant negative correlation between handgrip strength and somatic MRS score $(p=0.002)$ and total MRS score $(p=0.03)$. There was a significant

Keywords

- menopause

- quality of life

- muscle strength correlation between knee flexor strength and sit-to-stand time and all menopausal symptom areas $(p<0.05)$, except psychological symptoms. There was a positive correlation between physical performance of the knee flexors and quality of life items including occupational $(p=0.001)$, emotional $(p=0.005)$, and total UQOL $(p=0.01)$, but a negative correlation with sit-to-stand time and all quality of life domains $(p<0.05)$.
\end{abstract}

received

January 5, 2016

accepted

April 5, 2016

published online

May 19, 2016
DOI http://dx.doi.org/

$10.1055 / \mathrm{s}-0036-1584238$.

ISSN 0100-7203.
Copyright $(2016$ by Thieme Publicações License terms

Ltda, Rio de Janeiro, Brazil
(®) $\Theta \circledast$ 


\section{Resumo}

\section{Palavras-chave \\ - climatério \\ - qualidade de vida \\ - força muscular}

Conclusion A greater intensity of menopausal symptoms and worse quality of life were related with worse physical performance. Thus, preventive measures should be implemented to avoid adverse effects on physical performance at more advanced ages.

Objetivo Avaliar a relação entre sintomatologia climatérica e qualidade de vida no desempenho físico em mulheres de meia-idade.

Métodos Estudo transversal, realizado de abril a novembro de 2013, no município de Parnamirim/RN. A amostra foi composta por 497 mulheres (40 a 65 anos). Menopause Rating Scale (MRS) foi utilizada para a avaliação dos sintomas climatéricos e Utian Quality of Life (UQOL) para a qualidade de vida. Medidas de desempenho físico foram compostas pela força de preensão manual, força de extensores e flexores de joelho (usando um dinamômetro isométrico), velocidade de marcha e tempo de sentarlevantar. A relação da sintomatologia climatérica e qualidade de vida com o desempenho físico foi avaliada pelo teste de correlação de Pearson, sendo considerado um $p<0,05$ e intervalo de confiança de $95 \%$.

Resultados Houve correlação significativa negativa da força de preensão quanto ao MRS somático $(p=0,002)$ e total $(p=0,03)$. Para força de flexores de joelho e tempo de sentar-levantar, houve correlação significativa para todos os domínios dos sintomas climatéricos $(p<0,05)$, exceto o psicológico. Entre qualidade de vida e desempenho físico, houve correlação positiva dos flexores de joelho quanto ao UQOL ocupacional $(p=0,001)$, emocional $(p=0,005)$ e total $(p=0,01)$, e negativa para o teste sentarlevantar quanto a todos os domínios $(p<0,05)$.

Conclusão A maior intensidade dos sintomas climatéricos e a pior qualidade de vida apresentaram relação com piores desempenhos. Dessa forma, medidas de prevenção devem ser implementadas a fim de evitar consequências negativas no desempenho físico em idades mais avançadas.

\section{Introduction}

The aging process features a natural decline of physiological functions, including loss of bone mass, muscle mass, and strength. ${ }^{1}$ In Brazil as well as worldwide, population aging is marked by feminization, as women are achieving greater longevity than men. ${ }^{2}$ Although they live longer than men, women present worse physical performance results at more advanced ages, suggesting the influence of sex-related factors in performance changes with aging. ${ }^{3}$

Muscle mass in women tends to decrease gradually after the third decade of age, and displays an accelerated decline after the fifth decade, the average period of the occurrence of menopause. ${ }^{4}$ Menopause represents a biological milestone in the female lifespan, signaling the passage from a reproductive to a non-reproductive phase ${ }^{5}$ that is primarily related to decreases in estradiol and symptoms from hormonal changes in this period. ${ }^{6}$ In addition to muscle mass loss, a significant muscular strength loss occurs during the menopausal period that reflects negatively on the functional capacity of these women. ${ }^{3,7}$

Clinically, the hormonal changes typical of this phase are related to changes in the health status of women, such as negative implications on quality of life, emotional lability, interference in mood and sleep, and an increased risk of depression and cognitive difficulties. ${ }^{6,8}$ Together with these changes, some menopausal symptoms are related to lower physical activity levels, ${ }^{9}$ which could contribute to the worse physical performance levels found among women from middle age onward.

These changes during the menopause phase tend to impair quality of life and result from both hypoestrogenism-related biological factors and cultural and psychosocial factors. ${ }^{6,10}$ In addition, the ways women perceive such changes are distinct, as are the manifestations of menopausal symptoms and the way they interfere with quality of life and daily functioning. ${ }^{11}$ Thus, it is assumed that menopausal symptoms and quality of life perceptions are related to women's ability to perform daily living activities $^{12}$; also, the former may exacerbate the harmful effects of muscle mass and strength losses that occur during this period. ${ }^{13}$

Although some studies have investigated the influence of hormonal deficits and menopausal status on muscle changes in women, ${ }^{3,7,14}$ the correlation between menopausal symptoms and quality of life and physical performance have not received proper attention; therefore, the objective of this study is to evaluate the correlation between menopausal symptoms and quality of life and the physical performance of middle-aged women. 


\section{Methods}

The present study was conducted in the municipality of Parnamirim, located in the metropolitan region of Natal, capital of Rio Grande do Norte. This municipality is $100 \%$ urbanized and has $\sim 200,000$ inhabitants. This was a crosssectional study. Data from this study were collected from April to November 2013 in the Integrated Center for Teaching, Research and Extension (Nipec) of Parnamirim by trained interviewers using standardized protocols.

The study population consisted of women between 40 and 65 years of age residing in the Parnamirim municipality. A convenience sample of 500 women was assembled after project disclosure at the basic health units in the municipality. In order to participate in the study, women had to meet the following inclusion criteria: have between 40 and 65 years of age; no history of bilateral oophorectomy; no neurological or degenerative diseases, limb fractures, painful processes, or other conditions that could compromise the measurement of physical performance; and provide informed consent to participate in the study. Three women did not complete the evaluation and were excluded from the analysis for a final sample of 497 women.

This study followed the principles of the Declaration of Helsinki, and was approved by the Research Ethics Committee of the Universidade Federal do Rio Grande do Norte (opinion number 387.737). All volunteers signed a Free and Informed Consent Form in agreement with resolution $466 / 12$ of the Brazilian National Health Council.

\section{Procedures}

Physical performance was assessed using the following variables: handgrip strength, knee flexor and extensor strength, gait speed, and chair stand test. The handgrip strength was assessed in the dominant hand in kilogram-force (kgf) using a Jamar® dynamometer (Jamar, Irvington, NY, USA). The volunteer was positioned as recommended by the American Society of Hand Therapists: ${ }^{15}$ in a seated position with the shoulder adducted and in neutral rotation, the elbow positioned at $90^{\circ}$ flexion, and the forearm and wrist in neutral positions. Each participant was requested to perform three 5-second sustained contractions, with a 1-minute interval between the measurements. The mean of three measurements was included in the analysis.

A portable MicroFET2 ${ }^{\circledR}$ dynamometer (Hoggan, West Jordan, UT, USA) was used to measure the dominant knee flexor and extensor strength. Knee extension was assessed with the volunteer positioned in ventral decubitus on a stretcher with the knee flexed at $90^{\circ}$, and the thigh fixed to the stretcher by an inelastic band. The dynamometer was fixed by the examiner to the anterior surface of the lower end of the limb in a line immediately proximal to the malleolus. During the knee flexion strength assessment, the volunteer remained in the same position, but with the knee extended. The dynamometer was positioned on the posterior surface of the lower end of the limb immediately above the line of the malleolus. Measurements of three maximum isometric con- tractions of knee extension and flexion of 5 seconds each, with a 1-minute interval between them, were conducted, and the arithmetic mean of three measurements was calculated. $^{16}$

For the assessment of gait speed and chair stand test, the time to walk in the usual step for a distance of $4 \mathrm{~m}$ was measured in 2 attempts, and the slower time was used to calculate the gait speed in meters per second. For the chair stand test, the volunteer was asked to sit down and fully stand five times as fast as possible with their arms crossed over the chest. The time to carry out the task was used in the analysis. More details about these tests are available in the original article. $^{17}$

Menopause symptoms were assessed by the Menopause Rating Scale (MRS), which is composed of eleven items divided into three areas: somatic, psychological, and urogenital. The symptoms are classified according to the intensity of involvement reported by the women, where the value for each question can be $0-4$; the higher the score, the higher the perception of the symptom. This scale was initially standardized in German and subsequently validated for other languages, including Portuguese. ${ }^{18}$

Quality of life was assessed using the Utian Quality of Life (UQOL) scale, which was also validated for the Brazilian population. ${ }^{19,20}$ This instrument consists of 23 questions subdivided into occupational, health, emotional, and sexual areas. For each question, the volunteer should respond if the statement is very false (1), false (2), moderately true (3), true (4) or very true (5). At the end, the scores were added; the higher the score, the better the quality of life.

The volunteers' sociodemographic data and socioeconomic factors, such as age, years of schooling, stable union, and family income were collected. The latter was categorized into less than 3 times the minimum wages (MW), or 3 times the MW or higher. ${ }^{3}$ Weight $(\mathrm{kg})$ and height $(\mathrm{m})$ were also measured.

Physical activity habits were self-reported and defined as the regular practice of physical exercise at least three times a week for at least 30 minutes per session. Other data on life habits were also collected, such as walk per week and sitting time per day according to the guidelines of the short version of the International Physical Activity Questionnaire validated for Brazil. ${ }^{21}$ For the variable walk per week, the women were instructed to report how many days and how much time per day they walked for more than 10 minutes without stopping during the last week, either as a way to get from one place to another or as physical exercise. Subsequently, the volunteers were allocated into one of two categories: $<90$ minute/ week and $\geq 90$ minute/week. ${ }^{3}$ For the sitting time per day, women were requested to report how much time in a normal day they spent sitting at home or at work, relaxing, watching television or reading, and the variable was dichotomized in $\leq$ 4 hour/day or $>4$ hour/day. ${ }^{3}$

\section{Data Analysis}

The data were analyzed using SPSS version 20.0 (SPSS, Chicago, IL, USA). A descriptive analysis was initially performed using the measures of central tendency (arithmetic 
Table 1 Characterization of the sample $(N=497)$

\begin{tabular}{|c|c|c|c|}
\hline Variable & Mean \pm SD & $\mathrm{N}$ & $\%$ \\
\hline Age (years) & $49.9 \pm 5.6$ & & \\
\hline Schooling (years) & $8.1 \pm 4.2$ & & \\
\hline \multicolumn{4}{|l|}{ Family income } \\
\hline$\geq 3 \mathrm{MW}$ & & 148 & 29.8 \\
\hline$<3 \mathrm{MW}$ & & 349 & 70.2 \\
\hline \multicolumn{4}{|l|}{ Stable union } \\
\hline Yes & & 357 & 71.8 \\
\hline No & & 140 & 28.2 \\
\hline \multicolumn{4}{|l|}{ Physical activity } \\
\hline Yes & & 131 & 26.4 \\
\hline No & & 366 & 73.6 \\
\hline \multicolumn{4}{|l|}{ Walking time per week } \\
\hline$<90$ minutes & & 266 & 53.5 \\
\hline$\geq 90$ minutes & & 231 & 46.5 \\
\hline \multicolumn{4}{|l|}{ Sitting time } \\
\hline$<4$ hours per day & & 326 & 65.4 \\
\hline$\geq 4$ hours per day & & 171 & 34.4 \\
\hline Occupational UQOL & $26.03 \pm 4.2$ & & \\
\hline Health UQOL & $18.3 \pm 4.9$ & & \\
\hline Emotional UQOL & $20.3 \pm 4.0$ & & \\
\hline Sexual UQOL & $8.7 \pm 3.1$ & & \\
\hline Total UQOL & $73.4 \pm 10.9$ & & \\
\hline Somatic MRS & $7.1 \pm 3.7$ & & \\
\hline Psychological MRS & $8.0 \pm 4.4$ & & \\
\hline
\end{tabular}

Abbreviations: MW, minimum wage; MRS, Menopause Rating Scale; N, number; SD, standard variation; UQOL, Utian Quality of Life.

mean) and dispersion (standard deviation) for quantitative variables and absolute and relative frequencies for categorical variables. The correlation of menopausal symptoms and quality of life (both by the total score of the scales used and by the scores of the different areas) with the outcomes (muscular strength, gait speed, and sit-to-stand time) for normally distributed data was assessed by Pearson's correla- tion test. Significance of $p<0.05$ and a confidence interval of $95 \%$ were set for all tests.

\section{Results}

- Table 1 shows the characteristics of the sample in terms of independent and dependent variables. The women had a mean age of $49.9 \pm 5.6$ years. The study sample showed a low level of schooling ( $8.1 \pm 4.2$ years) and a low family income (70.2\% reported having a family income $<3$ times the MW). Regarding physical activity, $73.6 \%$ of the women reported not exercising regularly.

-Table 2 shows the results of the correlation analysis between menopausal symptoms and the physical performance measures. There was a weakly significant negative correlation between handgrip strength and somatic MRS $(p=0.002)$ and total MRS $(p=0.03)$. Regarding knee flexor strength and sit-to-stand time, there was a weakly significant correlation with all items of the MRS $(p<0.05)$, except the psychological domain. The higher the symptom intensity, the worse the physical performance, that is, the lower the strength and more time required to perform the chair stand test.

- Table 3 shows the results of the correlation analysis between the variables of quality of life and physical performance. Regarding knee flexor strength, a weakly significant correlation was found with occupational ( $p=0.001$ ), emotional ( $p=0.005)$ and total UQOL scores $(p=0.01)$. In addition, a significant negative correlation was observed between sit-to-stand time and all areas of the UQOL and total score $(p<0.05)$; the lower the perceived quality of life, the worse the physical performance.

\section{Discussion}

The objective of this study was to verify the correlation between menopausal symptoms and quality of life in the physical performance of middle-aged women. Significant correlations were found between the variables. Worse physical performance was associated with a higher perception of the intensity of menopausal symptoms and worse perception of quality of life. The correlation between menopausal stage and physical performance has already been the subject of previous studies, $3,7,14$ but the specific correlation between

Table 2 Correlation between physical performance and menopausal symptoms $(N=497)$

\begin{tabular}{|c|c|c|c|c|c|c|c|c|c|c|}
\hline \multirow{3}{*}{$\begin{array}{l}\text { Menopause Symptoms } \\
\text { (MRS scores) }\end{array}$} & \multicolumn{10}{|c|}{ Measures of physical performance } \\
\hline & \multicolumn{2}{|c|}{$\begin{array}{l}\text { Handgrip } \\
\text { strength (kgf) }\end{array}$} & \multicolumn{2}{|c|}{$\begin{array}{l}\text { Knee flexors } \\
\text { strength (kgf) }\end{array}$} & \multicolumn{2}{|c|}{$\begin{array}{l}\text { Knee extensor } \\
\text { strength (kgf) }\end{array}$} & \multicolumn{2}{|c|}{$\begin{array}{l}\text { Sit-and-stand } \\
\text { time (s) }\end{array}$} & \multicolumn{2}{|c|}{$\begin{array}{l}\text { Gait speed } \\
(\mathrm{m} / \mathrm{s})\end{array}$} \\
\hline & $r$ & $p$ & $r$ & $p$ & $r$ & $p$ & $r$ & $p$ & $r$ & $p$ \\
\hline Somatic & -0.14 & 0.002 & -0.10 & 0.01 & -0.08 & 0.05 & 0.11 & 0.01 & -0.07 & 0.11 \\
\hline Psychological & -0.03 & 0.42 & -0.03 & 0.48 & -0.03 & 0.52 & 0.06 & 0.15 & -0.02 & 0.53 \\
\hline Urogenital & -0.06 & 0.12 & -0.10 & 0.02 & -0.06 & 0.17 & 0.15 & 0.001 & -0.08 & 0.07 \\
\hline Total & -0.09 & 0.03 & -0.09 & 0.04 & -0.07 & 0.12 & 0.12 & 0.005 & -0.06 & 0.13 \\
\hline
\end{tabular}

Abbreviations: kgf, kilogram-force; m/s, meters per second; MRS, Menopause Rating Scale; r, Pearson correlation coefficient; s, seconds. 
Table 3 Correlation between physical performance and quality of life ( $N=497)$

\begin{tabular}{|c|c|c|c|c|c|c|c|c|c|c|}
\hline \multirow{3}{*}{$\begin{array}{l}\text { Variables } \\
\begin{array}{l}\text { Quality of Life } \\
\text { (UQOL) }\end{array}\end{array}$} & \multicolumn{10}{|c|}{ Measures of physical performance } \\
\hline & \multicolumn{2}{|c|}{$\begin{array}{l}\text { Handgrip } \\
\text { (kgf) }\end{array}$} & \multicolumn{2}{|c|}{$\begin{array}{l}\text { Knee flexion } \\
\text { (kgf) }\end{array}$} & \multicolumn{2}{|c|}{$\begin{array}{l}\text { Knee extension } \\
\text { (kgf) }\end{array}$} & \multicolumn{2}{|c|}{$\begin{array}{l}\text { Sit-to-stand } \\
\text { (s) }\end{array}$} & \multicolumn{2}{|c|}{$\begin{array}{l}\text { Gait speed } \\
(\mathrm{m} / \mathrm{s})\end{array}$} \\
\hline & $r$ & $p$ & $r$ & $p$ & $r$ & $p$ & $r$ & $p$ & $r$ & $p$ \\
\hline Occupational UQOL & 0.01 & 0.83 & 0.15 & 0.001 & 0.06 & 0.12 & -0.12 & 0.008 & 0.01 & 0.76 \\
\hline Health UQOL & 0.01 & 0.91 & -0.02 & 0.65 & -0.01 & 0.91 & -0.15 & 0.001 & -0.02 & 0.58 \\
\hline Emotional UQOL & 0.06 & 0.17 & 0.12 & 0.005 & 0.07 & 0.09 & -0.09 & 0.03 & 0.07 & 0.12 \\
\hline Sexual UQOL & 0.09 & 0.05 & 0.07 & 0.10 & 0.02 & 0.66 & -0.09 & 0.04 & -0.02 & 0.56 \\
\hline Total UQOL & 0.05 & 0.22 & 0.11 & 0.01 & 0.05 & 0.20 & -0.17 & $<0.001$ & 0.01 & 0.78 \\
\hline
\end{tabular}

Abbreviations: kgf, kilogram-force; m/s, meters per second; r, Pearson correlation coefficient; s, seconds; UQOL, Utian Quality of Life.

menopausal symptoms and physical performance has not been sufficiently investigated.

In a study that evaluated 1,011 women in different menopausal phases, a correlation was observed between menopausal symptoms and physical activity level. The authors observed that women with a lower physical activity level had higher menopausal symptom scores, both in frequency and intensity. ${ }^{9}$ The fact that women who present more intense symptoms are physically less active may explain the fact that they also have worse physical performance, since the practice of physical activity was a predictor of muscle strength loss in a longitudinal study of young postmenopausal women. ${ }^{22}$ Moreover, Gonçalves et $\mathrm{al}^{23}$ claimed that women who reported less severe menopausal symptoms presented better quality of life and physical performance results, probably due to the practice of physical activity. ${ }^{23}$ Thus, it is possible that physical activity improves quality of life, decrease the climacteric symptoms, increase the willingness to exercise and, consequently, avoid further loss of strength and muscle mass resulting from menopause, leading to a better physical performance. ${ }^{7,23,24}$ In the present study, $73.6 \%$ of participants reported not being physically active on a regular basis, which may have contributed to the presence of more intense symptoms, lower quality of life, and worse physical performance.

A normal phenomenon in a woman's lifetime, menopause is also a critical period of personal, social, and psychological development that is frequently faced with apprehension due to the changes that occur, which can negatively impact quality of life. ${ }^{25}$ Women must adapt to the multiple physical, psycho-affective, and sociocultural changes inherent to this process that can have repercussions on health status and quality of life. ${ }^{26}$ Both depression and fatigue are related to menopausal symptoms, ${ }^{27}$ while depressive symptoms are related to worse physical performance. ${ }^{28}$ Therefore, there may be a cycle in which menopausal symptoms discourage women and trigger depressive feelings, fatigue, and other effects. ${ }^{27}$ This leads these women to avoid physical activity or reduce their activities, which has the effect of reducing their physical performance. This reduction can induce negative feedback feelings and intensify this deficit.
Therefore, in this phase of female aging, menopausal symptoms also seem to correlate with worse physical performance, which is observed in the present study in terms of handgrip strength, knee flexor strength, and sit-and-stand test time, in which the worst physical performances were observed in women who reported a higher intensity of menopausal symptoms. Confirming such results, a recent study showed that as menopausal symptoms worsen, strength gradually decreases, displaying a negative correlation between menopausal symptoms and strength. ${ }^{29}$

Physical performance, evaluated by both muscle strength tests and sit-and-stand test time, may be influenced by clinical and physiological characteristics as well as social environment. ${ }^{3}$ Moreover, during aging, hormonal changes, with the consequent onset of symptoms, could be related to muscle strength and mass losses that usually occur during menopause in women. Therefore, these factors may explain the correlation found in this study between greater intensity of menopausal symptoms and lower muscle strength level. ${ }^{3}$

The World Health Organization defined the phrase "quality of life" as an individual's perception of their position in life in the context of the culture and value systems in which they live and in relation to their goals, expectations, standards, and concerns. ${ }^{30}$ The expression "health-related quality of life" refers to an individual's perception of the correlation between their physical (ability to perform physical activities), psychological (emotional stress, anxiety and depression), and social (family interaction, time for friends and leisure activities) limitations. ${ }^{31}$

A study of 4,261 individuals aged 20-79 years revealed that self-perceived quality of life could predict mortality risk. $^{32}$ It is also known that physical performance reductions are independently associated with subsequent disability, fracture, falls, hospitalization and mortality. ${ }^{33,34}$ However, the correlation between perceived quality of life and physical performance has not been analyzed to date. It is believed that a negative quality of life perception is also correlated with worse physical performance of these women during menopause, which was verified by the significant results in the present study between occupational, emotional, and total UQOL and knee flexion strength as well as between all items 
of the UQOL and total score with the sit-to-stand time. Women with lower quality of life scores had the worst physical performance levels. The finding noted in the present study can be one of the factors that explain the correlation between self-perceived quality of life and mortality.

The quality of these women's physical and psychological lives can be positively influenced by the daily practice of physical activity, leading to better body-mind harmony. 7,24 Therefore, the decrease in menopausal symptoms resulting from the practice of physical activity seems to improve quality of life, ${ }^{23}$ which in turn seems to contribute to improved physical performance. Schooling is another factor that may be correlated with menopausal symptom severity. ${ }^{6}$ De Lorenzi et $\mathrm{al}^{6}$ reported that menopausal symptoms seemed less intense among more highly educated women. Although schooling level was not evaluated in the present study, it can change the perception of menopausal symptoms ${ }^{6}$ and interfere with physical performance. ${ }^{35}$

One of the limitations of the present study is the lack of establishment of a causal relationship due to its transversal design. In addition, it is necessary to consider that our participants were middle-aged women in Northeast Brazil; therefore, one should be cautious about generalizing these results to other populations. These evaluations of menopausal symptoms and quality of life were based on the participants' self-reports, which can generate bias. However, validated questionnaires that are easy to apply and widely used in the literature, primarily in the context of epidemiological research, were applied here. Unlike independent variables, physical performance could be evaluated objectively using five measures, three of force and two that are also related to muscle power, an important point to be highlighted in this study.

\section{Conflict of Interest}

The authors declare no conflicts of interest.

\section{References}

1 Messier V, Rabasa-Lhoret R, Barbat-Artigas S, Elisha B, Karelis AD, Aubertin-Leheudre M. Menopause and sarcopenia: A potential role for sex hormones. Maturitas 2011;68(4):331-336

2 Instituto Brasileiro de Geografia e Estatística [Internet]. Expectativa de vida. 2013 [citado 2015 Jun 13]. Disponível em: http:// teen.ibge.gov.br/noticias-teen/7827-expectativa-de-vida

3 da Câmara SM, Zunzunegui MV, Pirkle C, Moreira MA, Maciel ACC. Menopausal status and physical performance in middle aged women: a cross-sectional community-based study in Northeast Brazil. PLoS ONE 2015;10(3):e0119480

4 Orsatti FL, Dalanesi RC, Maestá N, Náhas EAP, Burini RC. Redução da força muscular está relacionada à perda muscular em mulheres acima de 40 anos. Rev Bras Cineantropom Desempenho Hum. 2011;13(1):36-42

5 Ferreira VN, Chinelato RSC, Castro MR, Ferreira MEC. [Menopause: biopsychossocial landmark of female aging]. Psicol Soc 2013;25(2):410-419Portuguese.

6 Lorenzi DR, Catan LB, Moreira K, Ártico GR. Assistance to the climacteric woman: new paradigms. Rev Bras Enferm 2009;62(2): 287-293
7 Cheng MH, Wang SJ, Yang FY, Wang PH, Fuh JL. Menopause and physical performance-a community-based cross-sectional study. Menopause 2009;16(5):892-896

8 De Lorenzi DRS, Baracat EC, Saciloto B, Padilha I Jr. Factors related to quality of life in post-menopause. Rev Assoc Med Bras 2006; 52(5):312-317

9 Guimarães ACA, Baptista F. Relationship between physical activity and menopausal symptoms. Rev Bras Ativ Fís Saúde. 2011; 16(2):144-149

10 Brito NMB, Tavares NCS, Macedo LFC, Gonçalves BK. [Evaluation of the quality of life of climateric patients in a unit of health]. Rev Para Med. 2009;23(2):1-7Portuguese.

11 De Lorenzi DRS, Danelon C, Saciloto B, Padilha Júnior I. [Predicting factors of climacteric symptoms]. Rev Bras Ginecol Obstet 2005; 27(1):7-11Portuguese.

12 Aldrighi JM, Aldrighi CMS, Aldrighi APS. [Sistemic changes in climacterium]. Rev Bras Med 2002;59(4):15-21Portuguese.

13 Pierine DT, Nicola M, Oliveira EP. Sarcopenia: alterações metabólicas e consequências no envelhecimento. Rev Bras Ciênc Mov. 2009;17(3):96-103

14 Cooper R, Mishra G, Clennell S, Guralnik J, Kuh D. Menopausal status and physical performance in midlife: findings from a British birth cohort study. Menopause 2008;15(6): 1079-1085

15 Fess EE. Grip strength. In: American Society of Hand Therapists. Clinical assessment recommendations. 2nd ed. Chicago: The Society; 1992. p. 41-45

16 Martin HJ, Yule V, Syddall HE, Dennison EM, Cooper C, Aihie Sayer A. Is hand-held dynamometry useful for the measurement of quadriceps strength in older people? A comparison with the gold standard Bodex dynamometry. Gerontology 2006;52(3):154-159

17 Guralnik JM, Simonsick EM, Ferrucci L, et al. A short physical performance battery assessing lower extremity function: association with self-reported disability and prediction of mortality and nursing home admission. J Gerontol 1994;49(2): M85-M94

18 Heinemann K, Ruebig A, Potthoff P, et al. The Menopause Rating Scale (MRS) scale: a methodological review. Health Qual Life Outcomes 2004;2:45

19 Utian WH, Janata JW, Kingsberg SA, Schluchter M, Hamilton JC. The Utian Quality of Life (UQOL) Scale: development and validation of an instrument to quantify quality of life through and beyond menopause. Menopause 2002;9(6):402-410

20 Galvão LLLF. Tradução, adaptação e validação da versão brasileira do questionário utian quality of life (uqol) para avaliação da qualidade de vida no climatério [dissertação]. Natal: Universidade Federal do Rio Grande do Norte; 2007

21 Matsudo S, Araújo T, Matsudo V, et al. Questionário Internacional de Atividade Física (IPAQ): estudo de validade e reprodutibilidade no Brasil. Rev Bras Ativ Fís Saúde. 2001;6(2):5-18

22 Rolland YM, Perry HM III, Patrick P, Banks WA, Morley JE. Loss of appendicular muscle mass and loss of muscle strength in young postmenopausal women. J Gerontol A Biol Sci Med Sci 2007; 62(3):330-335

23 da Silveira Gonçalves AK, Gomes Canário AC, Leitão Cabral PU, et al. Impact of physical activity on quality of life in middle-aged women: a population based study. Rev Bras Ginecol Obstet 2011; 33(12):408-413

24 Llanas AC, Hachul H, Bittencourt LRA, Tufik S. Physical therapy reduces insomnia symptoms in postmenopausal women. Maturitas 2008;61(3):281-284

25 Nachtigall LE, Nachtigall MJ. Menopausal changes, quality of life, and hormone therapy. Clin Obstet Gynecol 2004;47(2): 485-488

26 Presado MHCV. Climatério/menopausa, relacionamento conjugal e qualidade de vida [tese]. Lisboa: Universidade Aberta; 2013

27 Penttinen HM, Saarto T, Kellokumpu-Lehtinen P, et al. Quality of life and physical performance and activity of breast cancer 
patients after adjuvant treatments. Psychooncology 2011;20(11):1211-1220

28 Gomes CdosS, Maciel ACC, Freire AdoN, Moreira MdeA, Ribeiro $\mathrm{MdeO}$, Guerra RO. Depressive symptoms and functional decline in an elderly sample of urban center in Northeastern Brazil. Arch Gerontol Geriatr 2014;58(2):214-218

29 Lee JY, Lee DC. Muscle strength and quality are associated with severity of menopausal symptoms in peri- and post-menopausal women. Maturitas 2013;76(1):88-94

30 World Health Organization [Internet]. International classification of impairments, disabilities, and handicaps: a manual of classification relating to the consequences of disease: published in accordance with resolution WHA29.35 of the Twenty-ninth World Health Assembly, May 1976. Geneva: World Health Organization; 1980 [cited 2015 May 18]. Available from: http:// www.who.int/iris/handle/10665/41003
31 Dennerstein L, Helmes E. The menopausal transition and quality of life : methodologic issues. Qual Life Res 2000;9(Suppl 1): 721-731

32 Haring R, Feng YS, Moock J, et al. Self-perceived quality of life predicts mortality risk better than a multi-biomarker panel, but the combination of both does best. BMC Med Res Methodol 2011;11:103

33 Sasaki H, Kasagi F, Yamada M, Fujita S. Grip strength predicts cause-specific mortality in middle-aged and elderly persons. Am J Med 2007;120(4):337-342

34 Studenski S, Perera S, Patel K, et al. Gait speed and survival in older adults. JAMA 2011;305(1):50-58

35 Kuh D, Bassey EJ, Butterworth S, Hardy R, Wadsworth MEJ; Musculoskeletal Study Team. Grip strength, postural control, and functional leg power in a representative cohort of British men and women: associations with physical activity, health status, and socioeconomic conditions. J Gerontol A Biol Sci Med Sci 2005;60(2):224-231 